\title{
Pengaruh Pupuk Kandang Ayam dan SP-36 terhadap Performa Sistem Perakaran dan Hasil Tanaman Kacang Tanah (Arachis hypogeae, Linn)
}

\author{
Nurhidayati ${ }^{1}$ dan Ramlah ${ }^{2}$ \\ 1,2 Sekolah Tinggi Pertanian Kutai Timur, Jl. Soekarno-Hatta No. 1, Sangatta Kutai \\ Timur, Kalimantan Timur \\ 1Email : hidasoil33@gmail.com \\ 2Email : ramlah@stiperkutim.ac.id
}

\begin{abstract}
The research aims to determine the interaction of chicken manure and SP-36, determine the optimum dose of chicken manure and SP-36 on the performance root system and the yield of groundnut. This study used a factorial randomized block design with 3 replications consisting of 2 treatment factors. The first factor were the 4 levels of chicken manure, i.e : P0 (0 tons.ha $\left.{ }^{-1}\right), P 1\left(5\right.$ tons. ha $\left.{ }^{-1}\right), P 2\left(10\right.$ tons. ha $\left.^{-1}\right), P 3$ $\left(15\right.$ tons.ha $\left.{ }^{-1}\right)$. Second factor were The 3 levels of SP-36, i.e: FO $\left(0 \mathrm{~kg}^{-h^{-1}}\right), F 1$ (150 $\left.\mathrm{kg} \cdot \mathrm{ha}^{-1}\right), \mathrm{F} 2\left(200 \mathrm{~kg} \cdot \mathrm{ha}^{-1}\right)$. The results showed that the interaction of manure chicken and SP-36 had not significant effect on root length, number of root nodules and pod wet weigh, but had a significant effect on root wet weight. The combination of chicken amnure 15 ton.ha ${ }^{-1}$ and SP-36 $200 \mathrm{~kg} \cdot \mathrm{ha}^{-1}$ gives the best root wet weight (7,33 gr.plant $\left.{ }^{-1}\right)$..

Keyword : Chicken manure, Root measurement, Root system, SP-36, Yield of groundnut
\end{abstract}

\section{ABSTRAK}

Penelitian ini bertujuan untuk mengetahui interaksi pupuk kandang ayam dan SP-36, menentukan dosis optimum pupuk kandang ayam dan SP-36 terhadap performa sistem perakaran dan hasil tanaman kacang tanah. Penelitian ini menggunakan Rancangan Acak Kelompok (RAK) Faktorial dengan 3 kali ulangan yang terdiri dari 2 faktor perlakuan. Faktor pertama 4 taraf pupuk kandang ayam masing-masing PO (0 ton.ha $\left.{ }^{-1}\right)$, P1 (5 ton.ha $\left.{ }^{-1}\right)$, P2 (10 ton.ha $\left.{ }^{-1}\right)$, P3 (15 ton.ha $\left.{ }^{-1}\right)$. Faktor kedua 3 Taraf SP36 masing-masing F0 $\left(0 \mathrm{~kg}^{-\mathrm{ha}^{-1}}\right)$, F1 $\left(150 \mathrm{~kg}^{-\mathrm{ha}^{-1}}\right)$, F2 $\left(200 \mathrm{~kg}^{-\mathrm{ha}^{-1}}\right)$. Hasil penelitian menunjukkan bahwa Interaksi perlakuan pupuk kandang ayam dan SP-36 tidak berpengaruh nyata terhadap panjang akar, jumlah bintil akar dan berat basah polong, tetapi berpengaruh nyata terhadap berat basah akar. Kombinasi pupuk kandang ayam 15 ton.ha- ${ }^{-1}$ dan SP-36 200 kg.ha- ${ }^{-1}$ memberikan berat akar terbaik (7,33 gr.tanaman $\left.{ }^{-1}\right)$. Kata Kunci: Hasil kacang tanah, Pengukuran akar, Pupuk kandang ayam, Sistem perakaran, SP-36.

\section{Pendahuluan}

Kacang Tanah (Arachis hypogeae, Linn) merupakan salah satu tanaman palawija yang digemari oleh masyarakat Indonesia. Dalam pemenuhan kebutuhan kacang tanah ditingkat pasar dan konsumen, Kabupaten Kutai Timur masih rendah, hal ini terbukti bahwa komoditi kacang tanah masih mendatangkan dari luar daerah. Komoditi pertanian ini termasuk langka ditingkat pasar, karena masih minim ketersediaannya, sehingga hargapun mahal. Tingginya harga kacang tanah seharusnya menjadi motivasi bagi petani, untuk meningkatkan budidaya tanaman kacang tanah.

Kendala menjadi indikator petani belum tergerak untuk budidaya kacang tanah karena kesuburan ultisol rendah. Kendala tersebut dapat diupayakan dengan pengembalian bahan organik, untuk mencapai produktivitas optimal dalam suatu lahan 
minimal mengandung bahan organik sebesar 2,5\% (Hatta, 2011). Bahan organik memiliki keunggulan dalam memulihkan kesuburan fisik, kimia dan biologi tanah, menjaga kestabilan suhu dan kelembaban tanah. Besarnya peran bahan organik mampu mendukung pertumbuhan dan produksi tanaman.

Pengembalian bahan organik berupa pupuk kandang ayam merupakan tindakan perbaikan lingkungan tumbuh tanaman, yang diharapkan dapat meningkatkan bahan organik tanah, mendukung kemantapan peningkatan produktivitas lahan dan sistem pertanian akan terlanjutkan (Salikin, 2003).

Teknologi budidaya pertanian saat ini masih bergantung pada pupuk anorganik termasuk fosfor yang berperan dalam mendukung pertumbuhan dan hasil kacang tanah lebih optimal. Fosfor sebagai unsur hara primer (Barchia, 2008) dan sumber energi berperan dalam berbagai aktivitas fotosintesis dan metabolisme energi dalam sel tanaman terutama sebagai penyimpan dan transfer energi di dalam proses biokimia tanaman (Sanchez, 2007). Dengan fosfor yang cukup, laju fotosintesis menjadi lebih optimal sehingga asimilat yang dihasilkan bagi pembentuk dan penyusun organ tanaman seperti akar, batang dan daun sisanya disimpan dalam bentuk protein dan karbohidrat.

Tujuan dari penelitian ini untuk untuk mengetahui interaksi pupuk kandang ayam dan SP-36, menentukan dosis optimum pupuk kandang ayam dan SP-36 terhadap performa sistem perakaran dan hasil tanaman kacang tanah. Hasil penelitian ini, diharapkan dengan penggunaan pupuk kandang ayam dan SP-36 dapat meningkatkan kesuburan tanah ultisol sehingga performa sistem perakaran dan hasil tanaman kacang tanah lebih optimal dan dapat diterapkan petani.

\section{Metode Penelitian}

Penelitian dilaksanakan di lahan tidur Jalan Soekarno-Hatta Sangatta Utara. Waktu pelaksanaan penelitian dimulai Februari sampai Mei 2017. Bahan yang digunakan dalam penelitian ini adalah benih tanaman kacang tanah varietas Gajah, pupuk kandang ayam, pupuk SP-36. Alat yang digunakan dalam penelitian ini adalah cangkul, tugal, tali, meterean, ember, gembor, penyemprot hama, sabit, parang, timbangan digital dan ATK seperti kertas HVS, spidol permanen, pulpen, kertas tabulasi data.

\section{Rancangan Penelitian}

Rancangan penelitian disusun dalam rancangan acak kelompok faktorial. Faktor pertama yaitu Pupuk Kandang Ayam ( $\mathrm{P}$ ) terdiri dari 4 taraf perlakuan : P0 (0 ton.ha ${ }^{-1}$ ), P1 (5 ton.ha- $\left.{ }^{-1}\right)$, P2 (10 ton.ha-1 $)$, P3 (15 ton.ha $\left.{ }^{-1}\right)$. Faktor kedua yaitu SP-36 (F) terdiri dari 3 taraf perlakuan : F0 (0 kg.ha-1), F1 (150 kg.ha-1), F3 (200 kg.ha-1). 


\section{Prosedur Penelitian}

Pengolahan tanah dilakukan dengan cara membajak dua kali dan meratakannya dengan cangkul. Pembuatan petak perlakuan ukuran $1 \mathrm{~m}$ × 1,8 $\mathrm{m}$ sebanyak 36 petak sesuai dengan perlakuan yang duji coba. Aplikasi pupuk kandang ayam diberikan 1 minggu sebelum tanam dengan menyebar pada sesuai perlakuan, aplikasi Fosfor 36 diberikan sekali pada saat tanaman berumur $60 \mathrm{HST}$, dengan cara tugal dan menutup kembali dengan tanah.

\section{Pengamatan}

\section{Analisis Performa Sistem Perakaran}

Performa sistem perakaran dilakukan pada empat sampel tanaman per petak dengan memotong bagian akar yang telah dipanen dan melakukan pengamatan terhadap rerata panjang akar, rerata jumlah bintil akar dan rerata berat basah akar Komponen Hasil

Hasil kacang tanah dilakukan dengan memanen polong basah dan melakukan pengamatan dan penimbangan terhadap berat basah polong empat sampel tanaman yang selanjutnya diambil rerata berat basah per tanaman.

\section{Analisis Data}

Data diuji dengan analisis ragam RAK faktorial, jika terdapat perbedaan nyata, maka untuk membandingkan dua rata-rata digunakan Uji Beda Nyata terkecil pada taraf signifikansi 5 \% (Gomez \& Gomez, 2010). Untuk menentukan efektivitas perlakuan terhadap peningkatan parameter dilakukan uji efektivitas dengan membandingkan perlakuan dengan kontrol (Tanpa Perlakuan).

\section{Hasil dan Pembahasan}

\section{Performa Sistem Perakaran}

\section{Panjang Akar}

Hasil analisis ragam menunjukkan bahwa perlakuan pupuk kandang ayam berpengaruh sangat nyata, namun perlakuan SP-36 dan interaksi kedua perlakuan berpengaruh tidak nyata terhadap panjang akar tanaman kacang tanah. Perbedaan nilai rerata panjang akar tertera pada Tabel 1. Hasil Uji BNT $5 \%$ (Tabel 1) terlihat bahwa aplikasi pupuk kandang ayam dosis 5 ton.ha-1 (P1) memberikan hasil panjang akar $16,11 \mathrm{~cm}$, nilai ini berbeda tidak nyata dengan P2 dan P3, namun berbeda nyata jika dibanding tanpa pupuk kandang ayam (P0).

\section{Jumlah Bintil Akar}

Hasil analisis ragam menunjukkan bahwa aplikasi pupuk kandang ayam berpengaruh sangat nyata, namun interaksi kedua perlakuan dan perlakuan SP-36 berpengaruh tidak nyata terhadap jumlah bintil akar. Perbedaan nilai rerata jumlah bintil 
ISSN 2354-7251 (print)

akar tertera pada Tabel 2. Hasil Uji BNT 5 \% (Tabel 2) terlihat bahwa aplikasi pupuk kandang ayam 15 ton.ha-1 $^{-1}$ (P3) memiliki jumlah bintil akar (36,11 bintil), nilai ini berbeda tidak nyata dengan $\mathrm{P} 1$ dan $\mathrm{P} 2$, namun berbeda nyata jika dibanding P0.

Tabel 1. Pengaruh dosis pukan ayam dan Fosfor SP-36 terhadap panjang akar tanaman kacang tanah

\begin{tabular}{ccccc}
\hline $\begin{array}{c}\text { Pengaruh Dosis } \\
\text { Pupuk kandang Ayam (P) }\end{array}$ & \multicolumn{2}{c}{ Pengaruh Dosis Fosfor SP-36 (F) } & \multirow{2}{*}{ Rerata P } \\
\hline & F0 & F1 & F2 & \\
P0 & \multicolumn{3}{c}{---- panjang akar (cm) ----} \\
P1 & 13,07 & 13,27 & 12,33 & $12,89 \mathrm{a}$ \\
P2 & 15,53 & 15,67 & 17,13 & $16,11 \mathrm{~b}$ \\
P3 & 15,07 & 16,93 & 14,80 & $15,60 \mathrm{~b}$ \\
Rerata & 15,47 & 15,20 & 14,87 & $15,18 \mathrm{~b}$ \\
\hline
\end{tabular}

Keterangan : P0 (5 ton.ha- $\left.{ }^{-1}\right)$, P1 (5 ton.ha- $\left.{ }^{-1}\right)$, P2 (10 ton.ha-1), P3 (15 ton.ha-1), F0 (0 kg.ha-1), F1 (150 kg.ha- $\left.{ }^{-1}\right)$, F2 (200 kg.ha-1). Angka-angka yang diikuti oleh huruf yang sama berarti berbeda tidak nyata pada Uji BNT $5 \%$. Nilai BNT $(P)=1,50$

Tabel 2. Pengaruh dosis pukan ayam dan SP-36 terhadap jumlah bintil tanaman kacang tanah

\begin{tabular}{ccccc}
\hline Pengaruh Dosis & \multicolumn{3}{c}{ Pengaruh Dosis SP-36 (F) } & \multirow{2}{*}{ Rerata P } \\
Pupuk kandang Ayam (P) & Fo & F1 & F2 & \\
\hline & ---- & jumlah bintil akar (biji) ---- & $16,27 \mathrm{a}$ \\
P0 & 21,67 & 13,27 & 13,87 & $33,56 \mathrm{~b}$ \\
P1 & 34,13 & 35,60 & 30,93 & $31,60 \mathrm{~b}$ \\
P2 & 30,60 & 33,67 & 30,53 & $36,11 \mathrm{~b}$ \\
\hline Rerata F & 38,60 & 33,20 & 36,53 & \\
\hline
\end{tabular}

Keterangan : P0 (5 ton.ha-1), P1 (5 ton.ha-1), P2 (10 ton.ha-1), P3 (15 ton.ha-1), F0 (0 kg.ha-1), F1 (150 kg.ha-1), F2 (200 kg.ha-1). Angka-angka yang diikuti oleh huruf yang sama berarti berbeda tidak nyata pada Uji BNT $5 \%$. Nilai BNT $(P)=8,75$

\section{Berat Basah Akar}

Hasil analisis ragam menunjukkan bahwa interaksi kedua perlakuan dan aplikasi pupuk kandang ayam berpengaruh sangat nyata, namun perlakuan SP-36 berpengaruh tidak nyata terhadap berat akar per tanaman. Perbedaan nilai rerata berat akar per tanaman kacang tanah tertera pada Tabel 3. Hasil Uji BNT 5 \% (Tabel 3) menunjukkan interaksi $\mathrm{P}_{3} \mathrm{~F}_{2}$ memberikan hasil berat akar yaitu 7,33 gram. Nilai ini berbeda tidak nyata dengan $\mathrm{P}_{2} \mathrm{~F}_{1}$ dan $\mathrm{P}_{3} \mathrm{~F}_{0}$, namun berbeda nyata dibanding kombinasi perlakuan lain. Secara terpisah aplikasi pupuk kandang ayam dosis 15 ton.ha $^{-1}$ memberikan hasil berat akar

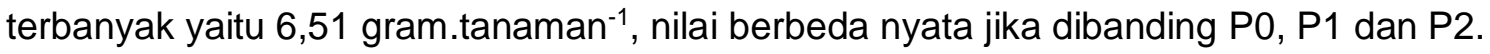

Tabel 3. Pengaruh dosis pukan ayam dan SP-36 terhadap berat basah akar

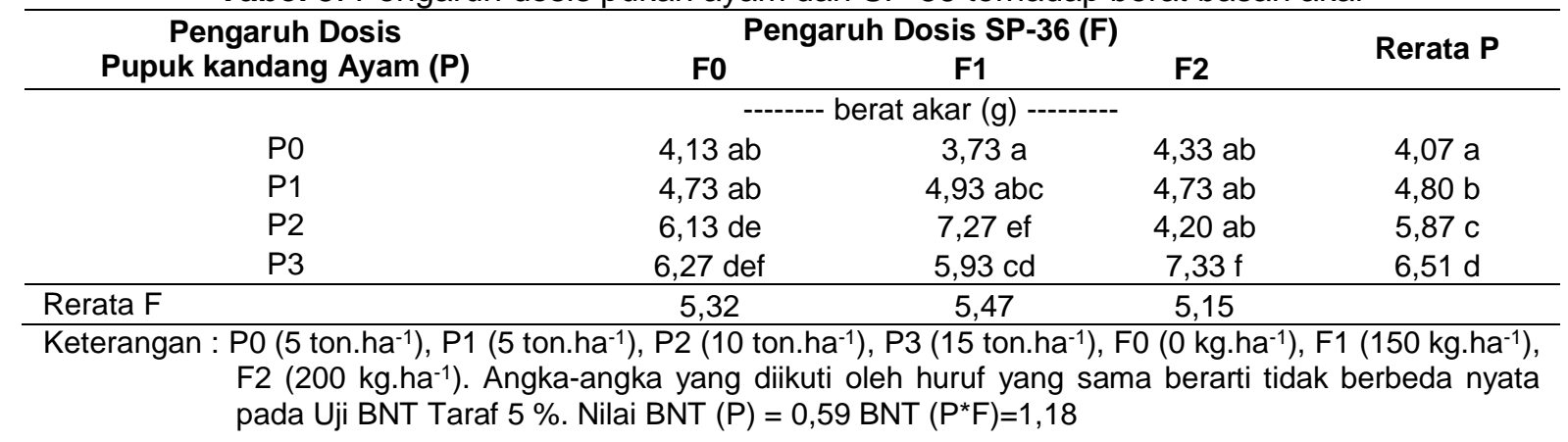


Hasil analisis ragam menunjukkan bahwa aplikasi pupuk kandang ayam berpengaruh sangat nyata dan perlakuan SP-36 berpengaruh nyata, namun interaksi kedua perlakuan berpengaruh tidak nyata terhadap berat polong basah per tanaman. Perbedaan nilai rerata berat polong basah kacang tanah tertera pada Tabel 4.

Tabel 4. Pengaruh Dosis Pukan Ayam dan SP-36 terhadap Berat Basah Polong Per Tanaman

\begin{tabular}{|c|c|c|c|c|}
\hline \multirow{2}{*}{$\begin{array}{c}\text { Pengaruh Dosis } \\
\text { Pupuk kandang Ayam (P) }\end{array}$} & \multicolumn{3}{|c|}{ Pengaruh Dosis SP-36 (F) } & \multirow{2}{*}{ Rerata P } \\
\hline & Fo & F1 & $\mathbf{F 2}$ & \\
\hline \multicolumn{5}{|c|}{--- berat basah polong (g. tanaman-1) ---- } \\
\hline P0 & 77,50 & 79,67 & 85,83 & $81,00 \mathrm{a}$ \\
\hline $\mathrm{P} 1$ & 95,17 & 99,67 & 106,00 & $100,28 \mathrm{~b}$ \\
\hline $\mathrm{P} 2$ & 106,83 & 108,00 & 109,67 & $108,17 \mathrm{bc}$ \\
\hline P3 & 103,00 & 109,33 & 116,33 & $109,56 \mathrm{c}$ \\
\hline Rerata F & $95,63 \mathrm{a}$ & $99,17 \mathrm{ab}$ & $104,46 \mathrm{~b}$ & \\
\hline
\end{tabular}

Keterangan : P0 (5 ton.ha-1), P1 (5 ton.ha-1), P2 (10 ton.ha-1), P3 (15 ton.ha-1), F0 (0 kg.ha-1), F1 (150 kg.ha $\left.{ }^{-1}\right)$, F2 (200 kg.ha $\left.{ }^{-1}\right)$. Angka-angka yang diikuti oleh huruf yang sama berarti berbeda tidak nyata pada Uji BNT Taraf $5 \%$. Nilai BNT $(P)=6,51$ BNT $(F)=9,20$

Hasil Uji BNT 5 \% (Tabel 4) terlihat bahwa perlakuan pupuk kandang ayam 15 ton.ha-1 menunjukkan hasil berat basah polong yaitu 109,56 g.tanaman ${ }^{-1}$, nilai ini berbeda tidak nyata dengan P2, namun berbeda nyata jika dibanding P1 dan P0. Perlakuan SP-36

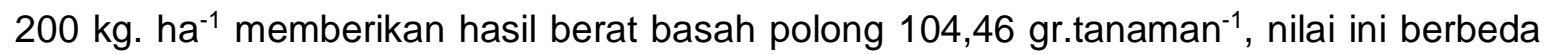
tidak nyata dengan F1 namun berbeda nyata jika dibanding F0.

\section{Efektivitas Pukan ayam dan SP-36 terhadap peningkatan sistem perakaran dan hasil kacang tanah}

Hasil uji efektivitas (Gambar 1.a dan b) terlihat bahwa kombinasi perlakuan pupuk kandang ayam 15 ton.ha- ${ }^{-1}$ dan SP-36 200 kg.ha ${ }^{-1}\left(P_{3} F_{2}\right)$ mampu meningkatkan berat basah akar 77,42\%. Perlakuan pupuk kandang ayam 15 ton.ha-1 (P3) mampu meningkatkan jumlah bintil akar $121,99 \%$, berat basah akar $60,11 \%$, dan berat basah polong tanaman kacang tanah $35,25 \%$.
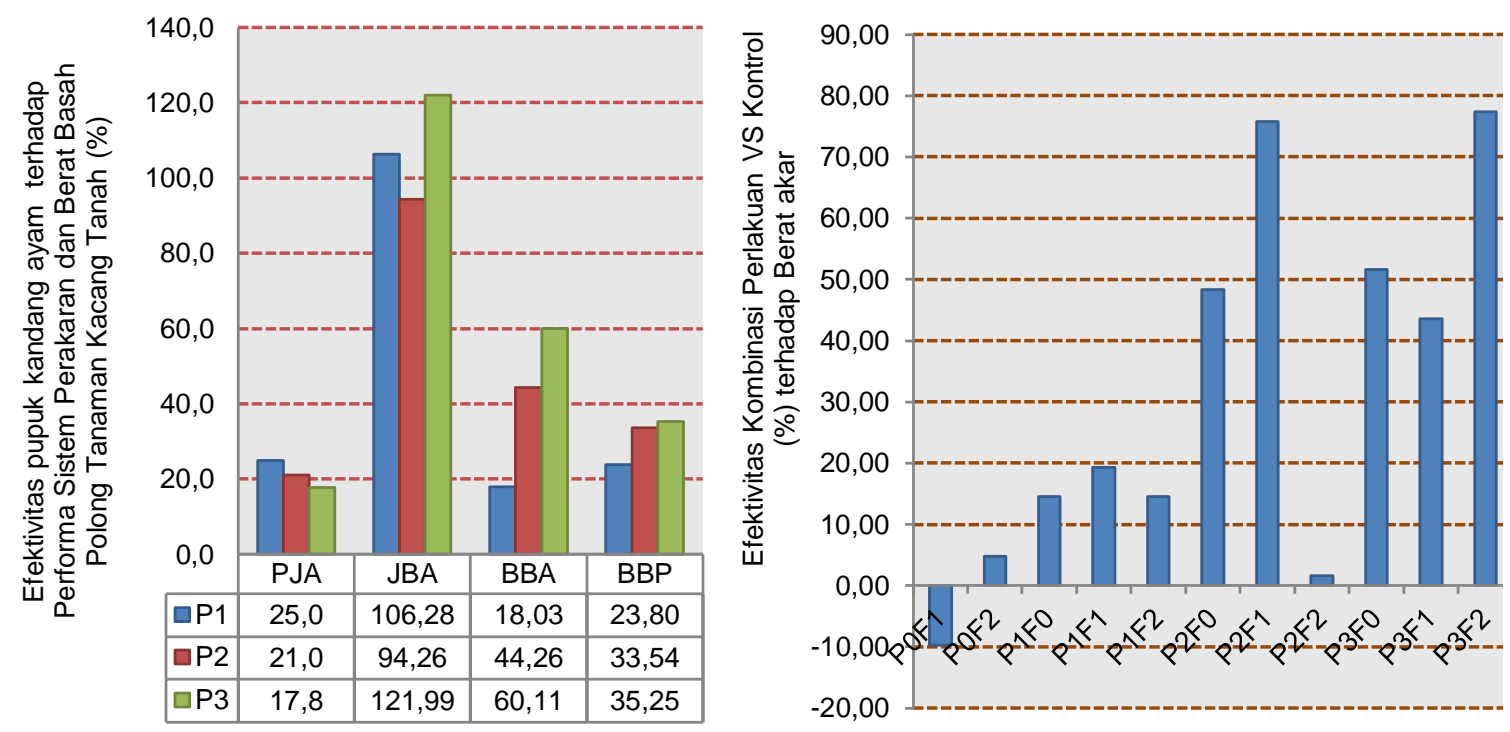

Gambar 1. a) Efektivitas pukan ayam terhadap panjang akar (PJA), ), jumlah bintil akar (JBA) dan berat basah akar (BBA) dan berat basah polong (BBP). b) efektivitas kombinasi perlakuan terhadap berat akar. 


\section{Pengaruh pupuk kandang ayam dan SP-36 terhadap performa sistem perakaran dan} hasil tanaman kacang tanah

Hasil analisis data secara statistik diketahui bahwa interaksi kedua perlakuan berpengaruh sangat nyata terhadap berat akar. Secara terpisah Perlakuan pupuk kandang ayam berpengaruh sangat nyata terhadap panjang akar, berat akar, jumlah bintil akar dan berat basah polong. Perlakuan SP-36 berpengaruh nyata terhadap hasil berat basah polong, tetapi tidak berpengaruh nyata terhadap panjang akar, jumlah bintil akar dan berat basah akar.

Pengaruh nyata pupuk kandang ayam terhadap seluruh parameter perakaran dan hasil dikarenakan peran pupuk organik mampu memperbaiki struktur tanah menjadi lebih gembur, sehingga volume perakaran menjadi lebih luas (Marpaung, 2014). Pertumbuhan vegetatif akar dan generatif memberikan respon terhadap penggunaan pupuk kandang ayam, hal ini diduga terjadi mineralisasi unsur hara sehingga berpengaruh baik terhadap pertumbuhan akar dan hasil tanaman kacang tanah.

Pupuk kandang ayam berpengaruh sangat baik terhadap kesuburan tanah dan pertumbuhan tanaman, bahkan lebihbaik dari pukan hewan besar (Hasibuan, 2010). Hara fosfor $(\mathrm{P})$ organik bagi tanaman lebih banyak berfungsi merangsang pertumbuhan akar, membantu asimilasi dan pernafasan, mempercepat pembungaan serta pemasakan biji dan buah. Kekurangan $\mathrm{P}$ berakibat menurunnya pembentukan buah dan biji, pertumbuhan kerdil dan daun berwarna keunguan atau kemerahan (Khair et.al., 2013).

Aplikasi pupuk kandang ayam 15 ton.ha-1 $^{-1}$ mampu meningkatkan berat akar $60,11 \%$ dan jumlah bintil akar 121,99 \% dibanding tanpa pupuk kandang ayam. Hal ini mengindikasikan pemberian pupuk organik berpengaruh baik dalam meningkatkan berat dan bintil akar. Hal ini diperkuat penelitian Noor (2003) bahwa kombinasi bakteri pelarut fosfat dan pukan pupuk kandang mampu meningkatkan bintil akar 36,05 \% dibanding tanpa bakteri pelarut fosfat dan pupuk kandang sapi 10.ton ha-1. Semakin banyak jumlah bintil akar, semakin banyak bakteri Rhizobium dalam tubuh tanaman.

Peran rhizobium (Sari \& Prayudyaningsih, 2015) bagi tanaman yaitu mengikat nitrogen bebas yang berada di udara menjadi ammonia $\left(\mathrm{NH}_{3}\right)$ yang diubah menjadi asam amino yang selanjutnya menjadi senyawa nitrogen yang diperlukan tanaman untuk tumbuh dan berkembang, sedang rhizobium memperoleh karbohidrat sebagai sumber energi dari tanaman inang. Rhizobium yang berasosiasi dengan tanaman legum mampu memfiksasi $100-300 \mathrm{~kg} \mathrm{~N} \mathrm{ha}^{-1}$ dalam satu musim tanam dan meninggalkan sejumlah $\mathrm{N}$ untuk tanaman berikutnya.

Interaksi kedua perlakuan pupuk kandang ayam dan SP-36 berpengaruh sangat nyata terhadap berat akar. Makin besar dosis pupuk kandang ayam dan Fosfor SP-36, makin tinggi nilai berat akar. Terlihat peningkatan berat akar pada interaksi $\mathrm{P}_{3} \mathrm{~F}_{2}$ lebih 
tinggi $(77,42 \%)$ dibanding faktor tunggal $P(60,11 \%)$. Hal ini mengindikasikan bahwa kombinasi antara pupuk kandang ayam dan SP-36 untuk mendukung pertumbuhan berat akar. Interaksi kedua perlakuan saling mempengaruhi berat akar. Peningkatan berat akar akan berpengaruh terhadap hasil kacang tanah.

Kombinasi pupuk kandang ayam dan fosfor menunjukkan interaksi berpengaruh nyata terhadap berat akar. Hal ini diperkuat oleh Barus et. al., (2015), bahwa peran fosfor diantaranya 1) mendorong pertumbuhan tunas dan akar tanaman, 2) meningkatkan aktifitas unsur hara lain seperti nitrogen dan kalium yang seimbang bagi kebutuhan tanaman, 3) bagi leguminosa, fosfor berfungsi mempercepat pembungaan dan pembentukan biji dan buah, 4) mempercepat masak polong.

Besarnya volume akar diduga fosfor yang diaplikasikan tersedia dalam tanah. Penyerapan P oleh akar didukung adanya dekomposisi bahan organik. Brady (1990) menjelaskan bahwa dekomposisi pupuk organik di dalam tanah menghasilkan beberapa unsur hara yang dibutuhkan oleh tanaman seperti N, P dan K. Kemampuan bahan organik meningkatkan $\mathrm{pH}$, dapat membebaskan $\mathrm{P}$ dari jerapan $\mathrm{Al}$ dan $\mathrm{Fe}$, sehingga $\mathrm{P}$ menjadi tersedia bagi tanaman. Ketersediaan hara mendukung proses fotosintesis dan respirasi berlangsung baik (Van Auken \& Freidrich, 2006).

Penggunaan pupuk kandang ayam 10 ton.ha ${ }^{-1}$ mampu meningkatkan hasil kacang tanah 97,95\% senada dengan penelitian Hulopi (2006) bahwa pupuk kandang ayam mampu meningkatkan berat basah polong 3,17\% dibanding tanpa pupuk kandang. Hal ini karena hara $\mathrm{P}$ dan $\mathrm{K}$ pada pupuk kandang ayam tersedia cukup bagi pertumbuhan akar, semakin berat akar dan banyak jumlah bintil akar semakin luas jelajah akar menyerap hara dalam tanah. Hara K sebagai unsur essensial primer (Munawar, 2011) diserap tanaman dalam jumlah yang besar. Pupuk kandang ayam mengalami dekomposisi, sehingga terjadi mineralisasi K. Kalium merupakan pengaktif dari sejumlah besar enzim yang berperan penting dalam proses fotosintesis dan respirasi, juga mengaktifkan enzim yang membentuk pati dan protein. Ketersediaan $\mathrm{K}$ dalam pukan ayam mendorong bertambahnya berat polong kacang tanah.

\section{Kesimpulan}

Interaksi kedua perlakuan pukan ayam dan SP-36 berpengaruh sangat nyata terhadap berat akar. Kombinasi P3F2 memberikan berat akar terbaik (7,33 gr/tanaman setara $\left.434,57 \mathrm{~kg} \cdot \mathrm{ha}^{-1}\right)$. Perlakuan pukan ayam berpengaruh sangat nyata terhadap panjang akar, berat akar, jumlah bintil akar dan produksi tanaman kacang tanah. Dosis Pukan ayam 15 ton.ha ${ }^{-1}$ mampu meningkatkan sistem perakaran dan produksi tanaman kacang tanah terbaik. Perlakuan SP-36 berpengaruh nyata terhadap produksi tanaman kacang tanah. Dosis SP-36 $200 \mathrm{~kg} \cdot \mathrm{ha}^{-1}$ mampu meningkatkan produksi tanaman kacang 
secara optimal. Penelitian ini menunjukkan peran pukan ayam yang dapat menjadi pilihan subtitusi pupuk anorganik pada budidaya kacang tanah. Meskipun demikian, penerapan pada varietas kacang tanah yang berbeda masih perlu diketahui lebih lanjut.

\section{Daftar Pustaka}

Noor, A. (2003). Pengaruh fosfat alam dan kombinasi bakteri pelarut fosfat dengan pupuk kandang terhadap $\mathrm{P}$ tersedia dan pertumbuhan kedelai pada ultisol. Jurnal Agronomi Indonesia (Indonesian Journal of Agronomy), 31(3).

Barus, W. A., Khair, H., \& Siregar, M. A. (2015). Respon pertumbuhan dan produksi kacang hijau (Phaseolus radiatus L.) akibat penggunaan pupuk organik cair dan pupuk TSP. AGRIUM: Jurnal IImu Pertanian, 19(1).

Barchia, M. F. (2008). Agroekosistem Tanah Mineral Masam. Yogyakarta: UGM Press.

Duaja, W. (2012). Pengaruh Pupuk Urea, Pupuk Organik Padat Dan Cair Kotoran Ayam Terhadap Sifat Tanah, Pertumbuhan Dan Hasil Selada Keriting Di Tanah Inceptisol (The Effect of Urea, Solid and Liquid Organic Fertilizer from Chicken Manure to Soil Properties and The Yield of. Bioplantae, 1(4).

Hasibuan, B.E. (2010). Pupuk dan Pemupukan. Fakultas Pertanian Universitas Sumatera Utara.

Hatta, M. (2011). Aplikasi perlakuan permukaan tanah dan jenis bahan organik terhadap indeks pertumbuhan tanaman cabe rawit. Jurnal Floratek, 6(1), 8-27.

Hulopi, F. (2006). Pengaruh Penggunaan Pupuk Kandang dan NPK Terhadap Pertumbuhan Dan Hasil Tanaman Kacang Tanah. Buana Sains, 6(2), 165-170.

Khair, H., Pasaribu, M. S., \& Suprapto, E. (2013). Respon pertumbuhan dan produksi tanaman jagung (Zea mays L.,) terhadap pemberian pupuk kandang ayam dan pupuk organik cair plus. Agrium.18(1):13-22.

Gomez, K. A., \& Gomez, A. A. (1995). Prosedur Statistik Untuk penelitian Pertanian Edisi Kedua Penerjemah: Endang Syamsudin dan Justika S. Baharsyah. UI Press. Jakarta.

Marpaung, A. E. (2014). Pemanfaatan pupuk organik padat dan pupuk organik cair dengan pengurangan pupuk anorganik terhadap pertumbuhan tanaman jagung (Zea mays L). Jurnal Saintech, 6(04), 8-15.

Melati, M., \& Andriyani, W. (2005). Pengaruh pupuk kandang ayam dan pupuk hijau Calopogonium mucunoides terhadap pertumbuhan dan produksi kedelai panen muda yang dibudidayakan secara organik. Jurnal Agronomi Indonesia (Indonesian Journal of Agronomy), 33(2).

Munawar, A. (2011). Kesuburan Tanah dan Nutrisi Tanaman. Bogor: Penerbit IPB Press

Rahmawati, N. (2005). Pemanfaatan Biofertilizer pada Pertanian Organik. Fakultas Pertanian. Universitas Sumatera utara. Medan.

Rao, S. (2007). Mikroorganisme Tanah dan Pertumbuhan Tanaman. UI-Press

Salikin, K.A. (2003). Sistem Pertanian Berkelanjutan. Yogyakarta: Kanisius.

Sari, R., \& Prayudyaningsih, R. (2015). Rhizobium: pemanfaatannya sebagai bakteri penambat nitrogen. Buletin Eboni, 12(1), 51-64. 
Van Auken, O. W., \& Freidrich, R. (2006). Growth and mycorrhizal infection of two annual sunflowers with added nutrients, fungicide or salts. Texas Journal Of Science, 58(3), 195-218. 